\title{
Protein structures hint at the shape of things to come
}

In less than a year, an Anglo-Canadian group has worked out the structures of 50 complex proteins that are relevant to human disease.

The recent explosion of genome sequence data led scientists to hope that working out protein structures could become automated and accelerated. To date, projects attempting this have faced criticism for taking too long to deliver. But the results from the Structural Genomics Consortium (SGC), which specializes in human proteins, mark the coming of age of the field. The group, which is based in Toronto and Oxford, says it will add a further 100 structures to its free-access database in the coming year.

Knowing the shape of a protein is crucial for understanding its biological function, and designing drugs to interact with it. For example, the SGC has just released the threedimensional structure of a human enzyme (pictured) that converts cortisone to the metabolic hormone cortisol.

"Mice that lack the gene for this enzyme do not develop diabetes, whatever their diet," says Aled Edwards, the consortium's executive director. "So this target is exciting the pharmaceutical industry at the moment."

The field of structural genomics aims to reveal the shapes of proteins by using the information obtained from genome-sequencing projects in automated, high-throughput schemes. These would synthesize thousands of proteins in vitro so that they could be examined by X-ray crystallography and nuclear magnetic resonance techniques, which are used to image molecules in three dimensions.

Techniques have come a long way since Max Perutz took 22 years to determine the first structure of a protein, haemoglobin (M. F. Perutz et al. Nature 185, $416-422 ; 1960)$. And increasing availability of genome sequence information in the past few years caused structural genomics initiatives to pop up all around the world.

Apart from the Anglo-Canadian group, Germany, Japan and the United States all started major structural genomics projects. The field got off to a slow start, and the ambitious, Berlin-based Protein Structure Factory, which was investigating human proteins, closed after it failed to secure more funding in 2004. But the rate at which structures are

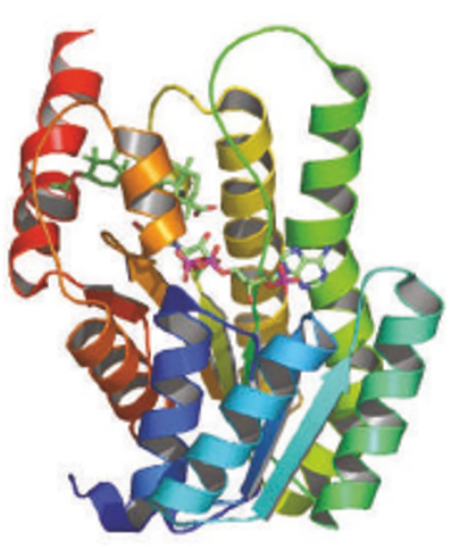

Mortalcoils: knowing the shape of enzymes is vital - this one could guide research in diabetes.

being published is starting to accelerate.

The US National Institute of General Medical Sciences, based in Bethesda, Maryland, started its Protein Structure Initiative (PSI) in 2000. By this summer, the PSI's nine 5-year projects will have delivered 1,100 structures nearly half of them produced in the past year.

And in a few weeks' time, the institute will announce the names of labs that have been selected to participate in the PSI's second phase. This will aim to deposit hundreds of protein structures in public databases each year.

But despite the impressive number of structures produced, the PSI has focused mainly on bacterial proteins. These are simpler than mammalian proteins and are therefore easier to make and purify. The SGC project is the first to solve the structures of a large number of human proteins.

The consortium's achievement is saluted "Cracking fifty Norvell. "Every step in the structures in less process is harder for human than year is $\quad$ proteins, says Norvell. Crackvery impressive." year is very impressive."

Norvell says that the US National Institutes of Health is planning pilot projects that will work out faster ways of capturing similarly difficult proteins.

He adds that after several years of building technologies, structural genomics initiatives are ready to roll out protein structures in large numbers.

Alison Abbott
ON THE RECORD

"You have to admit that evolution theory is not complete."

Dutch education minister, Maria Van der Hoeven, tells newspaper De Volkskrant why shesupports a public debate on intelligent design.

“I am very, very tired of the US signing on to international science agreements that we later come to regret."

Congressman Sherwood Boehlert (Republican, New York) supports an amendment to stall US irvolvement in the multibillion-dollar fusion experiment ITER until a clear source of funding can be found.

\section{"We need to ban the sale of long pointed kitchen knives."}

The British Medical Journal on how to reduce knife crime.

\section{THREE GOOD REASONS... ...to make your next car a hydrogen car}

Mileage Last week a prototype hydrogen car achieved a whopping 3,836 kilometres per litre of fuel.

Convenience for Californians. The state has just pledged to open 100 hydrogen-fuel stations around Los Angeles and San Francisco ... by 2010 .

Looks General Motors is developing a stylish hydrogen-powered Hummer.

\section{NUMBER CRUNCH}

50 - the number of years since the first atomic clock was unveiled at the National Physical Laboratory in Middlesex, UK.

0.16 - the number of seconds by which that original clock would be off if it was still running today.

0.1-the number of microseconds a modern atomic clock loses each year.

32-the number of "leap seconds" that have been added to atomic time since 1972 to adjust for a gradual slowing of Earth's rotation. 